\title{
Agama, Pendidikan, dan Tantangan Pemberantasan Korupsi di Indonesia
}

\author{
Entar Tarsih
}

\begin{abstract}
This article seeks to elaborate on the contribution of education in fighting corruption in Indonesia. By using the literature study method, this study found that the problem of corruption can be minimized through education because education is a human need. The concept of anti-corruption education is all efforts to reduce and eradicate corrupt behavior through programs in learning to provide awareness to individuals about the causes and consequences of corrupt behavior and encourage future generations to develop a firm resistance to any form of corruption. Learning programs that contain anti-corruption values are carried out in a meaningful manner so that they will remain strong in the minds of students so that they will firmly reject various forms of corruption.
\end{abstract}

Keywords: Corruption, education, meaningful learning

\section{Pendahuluan}

Krisis moralitas masih menjadi persoalan serius bangsa ini. Berbagai berita baik yang dirilis media cetak dan elektronik sekarang ini, sangat sering memberitakan merosotnya moralitas anak-anak bangsa. Berbagai kasus perbuatan menyimpang seperti perilaku korupsi telah banyak terjadi di masyarakat termasuk di sektor pemerintahan. Menurut Bank Dunia, korupsi di Indonesia terjadi di berbagai level golongan pegawai negeri sipil, tentara, polisi dan politisi, bahkan sudah melanda beberapa kelembagaan seperti Kepolisian, Kejaksaan, Peradilan, Dewan Perwakilan Rakyat (DPR) yang seharusnya bertugas untuk memberantas korupsi.

Korupsi seolah-olah telah mendarah daging dan menjadi persoalan akut bangsa Indonesia yang tak kunjung selesai. Berbagai upaya telah, sedang, dan akan dilakukan untuk mengurai benang kusut darinya, tapi hasilnya belum juga maksimal. Hasil rilis Harvard Bussiness Review per Oktober 2017 yang menampilkan indeks persepsi korupsi Indonesia saat ini berada di angka 37 dari rentang 0-100 menjadi penanda bahwa pemberantasan korupsi masih jauh dari harapan, walau sudah ada perbaikan. Lagi-lagi, Indonesia kalah dengan negara tetangga Malaysia, yang berada di angka 50 dalam indeks persepsi korupsinya. (Harto, 2014) 
Indonesia merupakan negara dengan pemeluk agama Islam terbanyak di dunia. Begitupula, Indonesia sebagai negara multikultural telah menetapkan 5 agama untuk dianut oleh bangsa Indonesia, serta terdapat beberapa kepercayaan yang menjadi tradisi di beberapa daerah. Hal ini mengindikasikan bahwa mayoritas bangsa Indonesia adalah pemeluk agama yangmana fungsi agama seharusnya adalah sebagai guide manusia untuk tetap berada di jalanNya, agar manusia menggapai kemaslahatan, ketenangan, keselamatan baik di dunia maupun di akhirat. Sebagaimana firman Allah dalam surat al-'Araf ayat 56: "Dan janganlah kamu membuat kerusakan di muka bumi, sesudah (Allah) memperbaikinya dan Berdoalah kepada-Nya dengan rasa takut (tidak akan diterima) dan harapan (akan dikabulkan). Sesungguhnya rahmat Allah Amat dekat kepada orang-orang yang berbuat baik."

Shihab (2005) menjelaskan dalam tafsirnya bahwa ayat ini menjeaskan tentang larangan berbuat kerusakan di muka bumi ini, yangmana berbuat kerusakan merupakan bentuk perbuatan yang melampaui batas. Alam semesta diciptakan oleh Allah SWT dalam keadaan yang harmonis, serasi dan memenuhi kebutuhan seluruh makhluk. Allah SWT telah menjadikannya dalam keadaan baik dan memerintahkan hambanya untuk memperbaikinya. Salah satu bentuk perbaikan yang dilakukan oleh Allah SWT ialah mengutus para Nabi dan Rasul untuk meluruskan dan memperbaiki kehidupan masyarakat. Untuk itulah, merusak setelah diperbaiki jauh lebih buruk daripada sebelum diperbaiki, karena ayat tersebut secara tegas memberikan keterangan tentang larangan berbuat kerusakan. (Shihab, 2005)

Penafsiran tersebut menggambarkan bahwa Allah mengutus para nabi dan rasul sebagai jalan untuk memperbaiki kehidupan manusia, yakni memberi pemahaman tentang bagaimana cara memperbaiki alam dan menjaganya. Realitasnya bahwa ada sebagian orang yang malah melakukan sebaliknya, ia memperparah dan merusak bumi karena selalu merasa kurang terhadap pemberian dari Allah SWT. Hal ini menjadi perbuatan yang amat buruk sebab merusak sesuatu yang telah diperbaiki lebih buruk dari pada sebelum adanya perbaikan.

Adapun dalam realitas yang kita hadapi bahwa banyak dari pemeluk agama itu terlibat pula dengan kasus-kasus korupsi di Indonesia. Alih-alih mereka menempatkan diri sebagai figur yang baik bagi para anggotanya dan masyarakat, mereka malah menjadi pelaku yang terjerumus dalam kasus korupsi. Hal ini menjadikan masyarakat sedikit demi sedikit terkikis kepercayaan mereka terhadap agama karena kehilangan sosok figur bagi kehidupannya.

Deskripsi di atas menggambarkan bahwa, fungsi agama belum sepenuhnya terealisasikan dalam kehidupan sehari-hari karena seolah-olah mereka menempatkan agama di tempat ibadah sedangkan di tempat bekerja mereka bebas berlalu lalang menggunakan uang/ sesuatu yang bukan haknya. Untuk 
itulah, perlu adanya suatu gebrakan agar pendidikan agama ini membekas dan melekat kuat dalam diri serta merealisasikannya dalam kehidupan sehari-hari.

Berkaitan dengan hal tersebut, pada tanggal 23 Oktober 2008, Ketua KPK telah menyerahkan modul Pendidikan Anti Korupsi kepada Mendiknas sebagai pertanda dimulainya kerja sama antara KPK dengan jajaran Depdiknas dalam pemberantasan korupsi dengan sekolah sebagai ujung tombaknya. Dalam kesempatan ini KPK menyebutkan bahwa modul untuk tingkat taman kanakkanak berbentuk buku dongeng. Materinya berisi tentang nilai kejujuran, kesederhanaan, kebersamaan, dan tolong-menolong. Adapun untuk tingkat SD, materinya merupakan kelanjutan dari tingkat di bawahnya. Adapun materi yang dibahas pada tingkat sekolah menengah pertama seputar definisi korupsi. Pada tingkat pendidikan berikutnya, sekolah menengah atas, modul memuat materi tentang uang negara, uang rakyat, dan sejarah perlawanan kaum muda terhadap korupsi. Adanya kurikulum pendidikan antikorupsi ini, jelas sekali menggambarkan bahwa pendidikan agama yang selama ini mengemban tugas perbaikan moral anak bangsa dipertanyakan. Pendidikan Agama Islam yang telah dipelajari sejak SD hingga Perguruan Tinggi dianulir dari mata pelajaran yang sanggup menanamkan nilai-nilai kejujuran dalam kehidupan setiap siswa. Hal ini juga berlaku sama dengan mata pelajaran lain, seperti pelajaran budi pekerti dan kewarganegaraan (Harto, 2014).

Menurut Maria Montessori dalam Gaffar (2016), pendidikan anti korupsi adalah program pendidikan tentang korupsi yang bertujuan untuk membangun dan meningkatkan kepedulian warga negara terhadap bahaya dan akibat dari tindakan korupsi. Target utamanya adalah memperkenalkan fenomena korupsi yang mencakup kriteria, penyebab dan akibatnya, meningkatkan sikap tidak toleran terhadap tindakan korupsi, menunjukkan berbagai kemungkinan usaha untuk melawan korupsi serta berkontribusi terhadap standar yang ditetapkan sebelumnya seperti mewujudkan nilai-nilai dan kapasitas untuk menentang korupsi di kalangan generasi muda. (Gaffar, 2016)

Sementara itu, menurut Sumiarti dalam Gaffar (2016) bahwa pendidikan anti korupsi merupakan tindakan untuk mengendalikan dan mengurangi korupsi berupa keseluruhan upaya untuk mendorong generasi mendatang untuk mengembangkan sikap menolak secara tegas terhadap setiap bentuk korupsi. Berpijak pada pengertian umum tentang pendidikan anti korupsi tersebut, maka pengertian dalam perspektif Islam pun hampir sama definisinya. Pendidikan anti korupsi menurut Islam adalah bentuk penyadaran dan pelarangan terhadap tindakan korupsi yang didasari dan dijiwai oleh sumber hukum Islam. (Gaffar, 2016)

Penyelenggaraan pendidikan anti korupsi ini bukan mutlak tugas sekolah/ pemerintah, tetapi perlu adanya kerjasama antara seluruh lingkungan pendidikan disebabkan untuk meminimalisir perilaku anti korupsi haruslah dibawah pengawasan. Keluarga sebagai institusi pendidikan pertama dan utama terlebih dahulu membangun perilaku tersebut pada masing-masing 
individu dalam keluarga, karena anak akan melihat seluruh perilaku anggota keluarga disebabkan rumah sebagai tempat paling lama anak menghabiskan waktunya. Adapun sekolah, secara profesional mempersiapkan program pendidikan ini secara matang mulai perencanaan, pengorganisasian, pelaksanaan dan evaluasi program pendidikan tersebut agar tujuan dari adanya program tersebut dapat terealisasikan.

Lingkungan masyarakat sebagai lingkungan pendidikan lanjutan memberikan motivasi dan penguatan dengan membangun atmosfer akhlakul karimah pada tiap-tiap individu di dalamnya. Untuk itulah, penting adanya komunikasi yang intensif antara ketiga lingkungan tersebut supaya program pendidikan anti korupsi terselenggara secara maksimal.

Berdasarkan hal tersebut, penulis merasa tertarik untuk memperdalam pembahasan tentang pendidikan anti korupsi sebagai suatu jalan untuk membentuk akhlak yang baik yang tertuang dalam judul "agama, pendidikan dan tantangan pemberantasan korupsi di Indonesia".

\section{METODE}

Penelitian ini menggunakan pendekatan kualitatif dan metode penelitian yang digunakan adalah non-interaktif karena tidak mengumpulkan data dari hasil interaksi dengan manusia sehingga jenis penelitian ini berupa metode deskriptif dan studi literatur.

Mukhtar (2013: 10) menjelaskan studi literatur yaitu menelusuri karyakarya besar yang dihasilkan oleh para pakar secara monumental atau menelusuri buku-buku teks yang digunakan dalam pembelajaran atau berbagai penelitian ilmiah. Sumber data primer dalam penelitian ini adalah modul pembelajaran PAI dan penelitian yang berkaitan tema pendidikan anti korupsi. Sedangkan sumber data sekunder berupa buku teks yang berkaitan dengan konsep pendidikan pascanatal. (Mukhtar, 2013)

Peneliti menggunakan teknik pengumpulan data dengan cara dokumentasi. Studi dokumentasi dilakukan dengan langkah-langkah berikut: pertama, menela'ah modul pembelajaran PAI berbasis pendidikan anti korupsi. Kedua, mendeskrisikan konsep pendidikan anti korupsi menurut modul-modul tersebut. Ketiga, menarik kesimpulan tentang konsep pendidikan anti korupsi berdasarkan pada modul yang telah ditela'ah.

\section{HASIL DAN PEMBAHASAN}

Pendidikan adalah upaya membentuk manusia yang memiliki pengetahuan yang baik, akhlak yang baik dan bisa menjadi manusia yang bermanfaat. Pendidikan dalam konteks pendidikan anti korupsi pada dasarnya menjauhkan manusia dari perilaku korup. Konsep pendidikan sudah sangat ideal, sebenarnya jika pendidikan berjalan sesuai dengan konsepnya maka tidak akan tumbuh generasi koruptor. Untuk itu, pendidikan Islam memegang andil yang cukup besar dalam memperbaiki nilai-nilai kehidupan. Pada dasarnya 
pendidikan Islam mendidik manusia menjadi manusia yang seutuhnya, manusia yang dimanusiakan. Artinya manusia yang mampu memegang teguh nilai-nilai akhlak kemanusiaan dalam perkembangan ilmu pendidikan dan perkembangan. Nilai akhlak itu diharapkan mampu bertahan di tengah maraknya kemerosotan nilai-nilai kemanusiaan, seperti terkuaknya kasuskasus korupsi di Indonesia. Di antara materi-materi pendidikan Islam, fokus penanganan korupsi seharusnya lebih diarahkan pada pendalaman dan penanam aqidah, di samping peningkatan penguasaan dan pemilikan akhlaqul karimah. Dengan penguasaan aqidah, setiap peserta didik dalam gerak perilakunya lebih dikendalikan dan dibimbing oleh spirit ketauhidan (Gaffar, 2016).

Pendidikan berasal dari pada kata "didik", yang ditambahkan awalan pe dan an sehingga menjadi "pendidikan" sebagaimana tercatat pada Kamus Besar Bahasa Indonesia artinya adalah proses rekayasa sikap dan tata prilaku sesorang atau sekelompok orang dalam upaya mendewasakan manusia melalui pengajaran dan pelatihan. Pendidikan tidak terlepas dari kegiatan "mendidik", yang memiliki arti memelihara dan melatihan. Dalam upaya memelihara dan melatihan diperlukan adanya pengajaran, intervensi, dan bimbingan mengenai akhlak dan upaya untuk mencerdasan pikiran (lihat Kamus Besar Bahasa Indonesia, 1991).

Pendidikan bertujuan untuk membentuk manusia sesuai dengan fitrah penciptaannya agar mendapatkan keselamatan dunia dan akhirat. Sebagaimana Ki Hajar Dewantara mengemukakan bahwa pengertian pendidikan adalah proses menuntun segala kekuatan kodrat yang ada pada anak-anak, peserta didik, agar mereka sebagai manusia dan sebagai anggota masyarakat dapat mecapai keselamatan dan kebahagiaan setinggi-tingginya.

Istilah pendidikan dalam pendidikan Islam dibagi pada 3 konteks pendidikan yaitu tarbiyah, ta'lim dan ta'dib.

\section{Pendidikan dalam konteks at-tarbiyah}

Pendidikan dalam Islam diistilahkan dengan "tarbiyah", yang bermakna mengasuh, memelihara, membuat, menjadikan bertambah dalam petumbuhan, membesarkan, memproduksi hasil-hasil yang sudah matang. Pemahaman yang lebih rinci mengenai tarbiyah ini harus mengacu kepada substansial yaitu pemberian pengetahuan, pengalaman dan kepribadian. Karena itu pendidikan Islam harus dibangun dari perpaduan istilah "ilm atau 'allama (ilmu pengajaran). 'adl (keadilan), 'amal (tindakan), haqq (kebenaran atau ketetapan hubungan dengan yang benar dan nyata, nuthq (nalar), nafs (jiwa), qalb (hati), 'aql (pikiran atau intelektual), meratib dan darajat (tatanan hirarkhis), ayat (tanda-tanda atau simbol), tafsir dan ta'wil (penjelasan dan penerangan), yang secara keseluruhan terkandung dalam istilah adab. (Al-Nahlawi., 1992)

An-Nahlawi (1992) mengemukakan bahwa makna pendidikan Islam dalam konteks at-tarbiyah memiliki substansi sebagai berikut: 1) memelihara serta 
menjaga fitrah peserta didik menuju kedewasaan, 2) mengembangkan seluruh potensi peserta didik menuju kesempurnaan, 3) memfokuskan seluruh fitrah peserta didik kepada kesempurnaan, 4) melakukan pendidikan secara terencana dan bertahap. (Al-Nahlawi., 1992)

Deskripsi di atas menggambarkan bahwa at-tarbiyah dimaknai sebagai sutau proses dalam memelihara, mengasuh serta menjadikan bertambah dalam petumbuhan seorang manusia melalui pemberian pengetahuan, pengalaman dan kepribadian menuju kedewasaan dan kesempurnaan sesuai dengan fitrah penciptaan manusia.

\section{Pendidikan dalam konteks at-ta'lim}

Kata at-ta'lim berasal dari akar kata 'allama-yu'allimu-ta'liman yang bermakna pengajaran, misalnya kata államahul 'ilma yang artinya mengajarkan kepadanya ilmu pengetahuan. Ridha memberikan penjelasan pada makna atta'lim adalah sebagai suatu proses transfer berbagai macam ilmu pengetahuan pada jiwa seseorang tanpa adanya batasan serta ketentuan khusus. (Mappasiara, 2018)

Kata at-ta'lim dapat kita jumpai pada firman Allah SWT dalam surat alBaqarah ayat 151: Sebagaimana (kami telah menyempurnakan nikmat Kami kepadamu) Kami telah mengutus kepadamu Rasul diantara kamu yang membacakan ayat-ayat Kami kepada kamu dan mensucikan kamu dan mengajarkan kepadamu Al kitab dan Al-Hikmah, serta mengajarkan kepada kamu apa yang belum kamu ketahui.

Ayat tersebut menggambarkan bahwa Rasulullah SAW diutus oleh Allah SWT untuk memberikan pengajaran ( $t a^{\prime} l i m$ ) kepada manusia berbagai hal untuk mereka ketahui sebagai jalan untuk mensucikan jiwa manusia.

\section{Pendidikan dalam konteks at-ta'dib}

Kata at-ta'dib memiliki akar kata yang serupa dengan kata adab yang berarti peradaban atau kebudayaan. Begitupula, istilah ini kerap diterjemahkan dengan kata sopan santun, budi pekerti, moral, etika, akhlak dan adab. Sebagaimana al-Attas mengemukakan bahwa konsep pendidikan yang cocok untuk istilah pendidikan Islam adalah $a t$-ta'dib. Kata ini terdapat dalam hadits Rasulullah SAW yang diriwayatkan oleh al-Asykari dari Aliy yang artinya: "Rabb-ku telah mendidikku, maka dia menyenpurnakan pendidikanku." (AlAttas., 1990)

Al-Attas mengemukakan makna $a t$-ta'dib sebagai suatu proses pengenalan dan bimbingan yang ditanamkan pada jiwa seorang manusia yang dilakukan secara berangsur-angsur sehingga ia akan akan meyakini dan mengakui tentang kekuatan dan keagungan Tuhan. (Al-Attas., 1990)

Makna pendidikan Islam dalam berbagai konteks memiliki kekhususan tersendiri yang sama-sama menunjukkan tentang substansi pendidikn itu sendiri yakni merupakan suatu proses membimbing, mengarahkan, 
memberikan pengetahuan untuk memelihara fitrah manusia supaya berada dalam kebenaran serta secara berangsur-angsur mendidik manusia menuju kedewasaan dan kesempurnaan agar senantiasa mengakui tentang kekuatan dan keagungan Tuhan.

Deskripsi di atas menggambarkan bahwa pendidikan memiliki substansi yang mulia dan agung sebagai proses untuk menjadikan manusia sebagai individu-individu yang berakhlakul karimah, yangmana hal tersebut sejalan dengan tujuan dari pendidikan Islam.

Tujuan pendidikan Islam sejalan dengan tujuan hidup manusia itu sendiri, yakni membentuk manusia yang berakhlak mulia, berbakti kepada Allah SWT secara totalitas, mengelola alam dengan benar sehingga terjaga keseimbangannya, serta menjalankan kehidupan sesuai dengan ajaran agama. Senada dengan hal tersebut, tujuan pendidikan Islam juga adalah untuk menanamkan taqwa dan akhlaq mulia serta menegakkan kebenaran dalam rangka membentuk manusia yang berkepribadian dan berbudi luhur menurut ajaran Islam. Dasar tujuan pendidikan Islam adalah membimbing pertumbuhan ruhani dan jasmani anak dengan cara mengajarkan, mengarahkan, melatih, mengasuh dan mengawasinya agar berjalan sesuai dengan ajaran agama Islam (Mappasiara, 2018). Untuk itulah, tujuan pendidikan Islam adalah penyerahan diri secara totalitas kepada sang pencipta Allah SWT. Sebagaimana dalam firman Allah SWT dalam surat adz-Dzariyat ayat 56 yang menyatakan bahwa Allah tidak menciptakan jin dan manusia kecuali hanya untuk menyembah kepada-Nya. "Dan aku tidak menciptakan jin dan manusia melainkan supaya mereka mengabdi kepada-Ku. (QS. Adz-Dzariyat [51]: 56

Shihab (2005) mengemukakan bahwa ayat tersebut menekankan pada perintah beribadah kepada-Nya semata-mata, maka redaksi yang digunakannya berbentuk tunggal dan tertuju kepada-Nya tanpa memberi kesan adanya keterlibatan selain Allah. Ibadah terdiri dari ibadah murni (mahdhah) dan ibadah tidak murni (ghairu mahdhah). Ibadah mahdhah adalah ibadah yang telah ditentukan oleh Allah, bentu, kadar atau waktunya seperti shalat, zakat, puasa dan haji. Ibadah ghairu mahdhah adalah segala aktivitas lahir dan batin manusia yang dimaksudkannya untuk mendekatkan diri kepada Allah. (Shihab, 2005)

Penafsiran tersebut menggambarkan bahwa Allah SWT tidak melibatkan hambanya satupun atas penciptaan seorang manusia, yangmana ini menandakan bahwa penyembahan semata-mata hanya kepada-Nya karena tidak ada sesuatu apapun yang mampu menandingi kekuasaan-Nya. Untuk itulah, pendidikan seyogyanya mampu membentuk peserta didik yang dapat mengerahkan dirinya secara totalitas dimanapun ia berada dan apapun posisi atau jabatannya, sehingga lingkungan di sekitarnya akan mendapatkan kebermanfaatan darinya, karena manusia yang bermanfaat adalah sebaik-baik makhluk di sisi Allah. 
Setelah manusia dapat membentuk dirinya sebagai hamba yang ta'at, tujuan pendidikan Islam selanjutnya adalah menjadikan manusia sebagai Khalifah Allah di muka bumi ini, sebagaimana firman Allah SWT dalam surat alBaqoroh ayat 31: Dan Dia mengajarkan kepada Adam Nama-nama (bendabenda) seluruhnya, kemudian mengemukakannya kepada Para Malaikat lalu berfirman: "Sebutkanlah kepada-Ku nama benda-benda itu jika kamu mamang benar orang-orang yang benar!" (QS. al-Baqarah [02]: 31)

Ayat di atas menggambarkan bahwa manusia merupakan makhluk Allah yang dilebihkan atas makhluk lainnya dengan diberikannya alam ini sebagai tempat ia hidup dan memanfaatkan segala hal yang ada di dalamnya. Untuk itulah, fungsi manusia sebagai khalifah Allah SWT di bumi ini adalah diberi amanat untuk mengelola alam dan menjaganya. Atas dasar hal itulah, hendaknya peserta didik dibimbing dan dibina untuk dapat melestarikan alam ini dengan cara memanfaatkan segala hal yang ada di bumi dan mengolah dengan benar untuk kemaslahatan ummat.

Adapun dalam merumuskan tujuan pendidikan Islam, ada beberapa hal yang perlu diperhatikan: a). Tujuan dan tugas manusia di muka bumi. Baik secara vertikal maupun horizontal. Sifat-sifat manusia tuntutan masyarakat dan dinamika peradaban. b). Dimensi-dimensi kehidupan ideal Islam. (Mappasiara, 2018)

Adapun dalam realitasnya, kita menemukan bahwa orang-orang yang berpendidikan baik cendekiawan, ulama, agamawan maupun para pejabat masih saja melakukan hal-hal menyimpang dari substansi pendidikan itu sendiri. hal ini menjadi suatu problematika dalam dunia pendidikan, karena pendidikan masih terus berlangsung namun substansinya seolah-olah hilang dan tidak membekas sama sekali pada mereka yang mencari ilmu. Untuk itulah, perlu adanya inovasi dalam pendidikan khususnya dalam proses pembelajaran supaya pembelajaran ini berlangsung secara maksimal yang diharapkan mampu membentuk manusia yang cerdas.

\section{Pendidikan Anti Korupsi}

Korupsi merupakan perilaku seseorang yang dapat merugikan khalayak disebabkan seseorang memiliki kekuasaan atas suatu hal. Korupsi adalah tingkah laku individu yang menggunakan wewenang dan jabatan guna mengeduk keuntungan pribadi, merugikan kepentingan umum. Korupsi merupakan perbuatan curang yang merugikan Negara dan masyarakat luas dengan berbagai macam modus. (Imelda, 2017)

Pendidikan anti korupsi bermaksud meminimalisir kesewenang-wenangan seseorang agar tidak merugikan khalayak ramai yang direalisasikan dalam program-program pendidikan melalui modul pembelajaran terutama modul pembelajaran agama.

Pendidikan anti korupsi merupakan suatu program pendidikan yang dimaksudkan untuk meningkatkan kepedulian dan kesadaran setiap warga 
negara tentang bahaya korupsi serta sebab dan akibatnya perilaku tersebut. Sebagaimana Montessori (2012) mengemukakan dalam Gaffar (2016) bahwa pendidikan anti korupsi adalah program pendidikan tentang korupsi yang bertujuan untuk membangun dan meningkatkan kepedulian warga negara terhadap bahaya dan akibat dari tindakan korupsi. Target utamanya adalah memperkenalkan fenomena korupsi yang mencakup kriteria, penyebab dan akibatnya, meningkatkan sikap tidak toleran terhadap tindakan korupsi, menunjukkan berbagai kemungkinan usaha untuk melawan korupsi serta berkontribusi terhadap standar yang ditetapkan sebelumnya seperti mewujudkan nilai-nilai dan kapasitas untuk menentang korupsi di kalangan generasi muda. (Gaffar, 2016)

1) Pembelajaran bermakna sebagai pembentukan perilaku anti korupsi

Pembelajaran dimaknai sebagai suatu usaha untuk membangun pengalaman-pengalaman baru bagi siswa. Proses belajar ini pasti dilalui oleh siswa dan guru dalam jangka waktu tertentu. Untuk itulah, penting bagi guru untuk membangun iklim pembelajaran yang mampu menumbuhkan minat siswa serta memberikan pengalaman-pengalaman baru bagi mereka melalui pemecahan masalah yang dialami oleh siswa yang didasarkan atas konsepkonsep yang relevan. Hal ini dimaksudkan agar pembelajaran ini membekas kuat dalam benak siswa sehingga bermakna bagi diri mereka. (Hude, 2018)

Pembelajaran yang bermakna merupakan suatu usaha untuk membuat peserta didik memahami dan mengerti suatu pembelajaran baik mata pelajaran berupa hitung-hitungan, sains maupun mata pelajaran agama bukan hanya mengingat atau menghafalkan materi.

Mengerti dan memahami sesuatu diperoleh saat manusia seseorang menghubungkan konsep-konsep baru dengan konsep lama. Maksudnya, seseorang menghubungkan pengetahuannya tentang sesuatu pada waktu terdahulu dengan pengetahuan yang ia dapatkan kini sebagai suatu hubungan yang menyebabkan diperolehnya suatu pemecahan masalah. Pembelajaran bermakna sangat bermanfaat karena memungkinkan peserta didik belajar berdasarkan pada realita sehingga menghasilkan pemahaman yang lebih besar. Sebagaimana Andrian (2017) mengemukakan bahwa pembelajaran bermakna memungkinkan peserta didik menghasilkan pemahaman yang lebih besar serta memfasilitasi proses pembelajaran untuk situasi yang nyata. (Andrian, 2017)

Selama ini pembelajaran lebih fokus pada pengembangan aspek kognitif siswa saja, dengan hanya diberlakukannya standar evaluasi berupa menjawab soal/ hanya mengevaluasi kemampuan berpikir peserta didik dan mengabaikan aspek afeksi dan psikomotorik, sehingga peserta didik hanya berfokus pada proses menghafal saja. untuk itulah, pembelajaran bermakna menjadi salah satu cara untuk membentuk peserta didik yang cerdas, serta sehat jasmani dan rohaninya.

Pembelajaran menjadi satu proses interaksi pendidik dan peserta didik. Pendidik berperan penting dalam berlangsungnya suatu pembelajaran baik 
melalui pendekatan student centred maupun teacher centred. Begitupula, pendidik juga didukung oleh kinerja kepala sekolah sebagai manager yang mampu mengelola sumber daya manusia nya menjadi individu-individu yang profesional. Untuk itulah, dalam mewujudkan pembelajaran bermakna dapat dilakukan langkah-langkah sebagai berikut:

a) Perencanaan pembelajaran yang matang

Pembuatan rencana pelaksanaan pembelajaran (RPP) menjadi suatu kegiatan yang substansial supaya dapat mewujudkan pembelajaran bermakna. seorang pendidik yang merencanakan pembelajarannya dapat memenej keberlangsungan pembelajaran terutama dalam penggunaan metode pembelajaran, karena tidak ada suatu metode pembelajaran yang dianggap paling cocok atau paling sempurna disebabkan kondisi peserta didik, waku belajar, jumlah peserta didik dan sebagainya.

Selanjutnya, dengan adanya perencanaan, pendidik dapat mengantisipasi dan memberikan tindakan yang tepat saat pembelajaran tidak berjalan sesuai rencana. Untuk itulah, kepala sekolah hendaknya terus memberikan bimbingan kepada guru untuk lebih baik dari waktu ke waktu, maka akan tercipta lingkungan sekolah yang saling mendukung satu dengan lainnya.

Selain itu, selama ini pembelajaran hanya berfokus pada mengingat dan mengahafal materi. Pendidik hendaknya melakukan inovasi dengan mengaitkan pembelajaran dengan peristiwa yang berada di sekitar siswa, misalnya dalam pembelajaran Aqidah Akhlak tentang hukum sunnah. Pengertian sunnah yang awalnya jika melakukan ibadah tersebut mendapat pahala, namun apabila meninggalkannya tidak apa-apa, kiranya hal ini bisa diganti dengan pengertian yang lebih mengarah kepada kebermaknaan, yaitu sunnah adalah dengan kalian melakukan ibadah-ibadah yang dicontohkan oleh Rasulullah SAW akan mendatangkan rahmat Allah dan kasih sayangnya, kemudian memberikan contoh yang relevan dengan kehidupan siswa, misalnya mempersilahkan orangtua duduk dikursi saat di dalam bus, membantu seseorang menyeberang jalan, membantu membawakan barang belanjaan atau yang berhubungan dengan ibadah ritual misalnya shalat dhuha, puasa sunnah, tahiyatul masjid dan sebagainya.

Selanjutnya, media pembelajaran interaktif juga berpengaruh terhadap pemahaman peserta didik tentang materi yang dipelajarinya. Berdasarkan hasil penelitian diperoleh hasil belajar kognitif siswa, yang berupa hasil tes tulis tergambarkan bahwa 92,05\% siswa mampu menjawab secara baik dan benar serta wawasan keilmuan yang luas. Hal ini mengindikasikan bahwa hasil belajar yang tinggi. Adapun 7,95\% siswa mampu menjawab dengan baik dan kurang dalam menggambarkan fenomena keilmuan terkini. Hasil tes tulis ini bukan berupa ingatan yang dihasilkan dari proses hafalan siswa, namun lebih berfokus pada hasil olah pikir siswa tentang materi yang kemudian diinternalisasikan dengan masalah dan fenomena dalam masyarakat. (Andrian, 2017) 
Hasil tersebut didapatkan melalui media pembelajaran post it. Post it dapat dimanfaatkan sebagai media pembelajaran, yang sangat membantu siswa dalam proses pembelajaran, terutama dalam konteks pembelajaran bermakna. Post It merupakan potongan kertas berukuran kecil dengan berbagai macam warna dan terdapat strip lem di bagian atasnya. Post it biasa dipakai untuk penanda bacaan atau dapat juga digunakan sebagai pengingat atau catatan kecil yang ditempel dalam buku.

b) Keteladanan dari lingkungan pendidikan anak

Keteladanan senantiasa memberikan pengaruh kuat terhadap diri anak. Saat anak berinteraksi dengan orang dewasa ia akan melihat, mendengar, mengenal dan mempelajari apa yang berada dari luar diri mereka. Untuk itulah, jika orang dewasa dapat selalu menjadi teladan dengan menunjukan perbuatan-perbuatan yang baik maka anak-anak akan terpengaruh dan mencontoh kepada hal yang baik pula. Sebagaimana Al-Ghazali menggambarkan bahwa orang tua adalah cerminan anak-anak, ini artinya perilaku orang tua akan ditiru oleh anak-anaknya, karena anak adalah peniru yang ulung. (Iswandi, 2019)

Keteladanan merupakan suatu sikap yang dicerminkan oleh seseorang baik disengaja ditampakkan untuk dijadikan figur oleh orang lain maupun perilaku baik yang ditimbulkan tanpa sengaja karena telah menjadi kebiasaan. Untuk itu, dalam menanamkan karakter pada anak sangat dibutuhkan sosok figur yang dapat ditemukan oleh peserta didik di lingkungan sekitarnya. (Iswandi, 2019)

Lingkungan pendidikan anak baik lingkungan rumah, sekolah dan masyarakat hendaknya dibangun suatu iklim pendidikan yang mendukung dan memberikan motivasi kepada anak agar dapat merealisasikan pengetahuannya, memberikan pemahaman tentang sesuatu dan dapat mengembangkan potensi mereka.

Sekolah sebagai lembaga pendidikan yang menjadi tumpuan harapan orangtua dan masyarakat diharapkan mampu membangun relasi bersama masyarakat dan orangtua siswa supaya lingkungan pendidikan ini berfungsi sebagai figur bagi anak. sekolah dapat memulainya dengan mengadakan program yang melibatkan kedua belah pihak untuk berperan aktif dalam kegiatan tersebut, misalnya mengadakan program parenting, selain ilmu yang didapatkan tentang pendidikan anak, hal ini pun sedikit demi sedikit membangun kerjasama antara ketiga lingkungan pendidikan anak dan diharapkan akan terbangun relasi positif untuk bersama-sama membentuk sumber daya manusia yang unggul.

\section{KESIMPULAN}

Dekadensi moral menjadi suatu permasalahan yang membutuhkan kerjasama dan usaha yang maksimal dalam pemecahannya. Korupsi menjadi satu perilaku yang banyak menjangkit warga negara Indonesia baik di ranah 
pemerintahan, agamawan maupun masyarakat pada umumnya. Pendidikan anti korupsi telah menjadi satu program pembelajaran yang diharapkan mampu membentuk generasi muda untuk menolak tegas segala hal yang mengandung unsur perilaku korupsi. Pendidikan anti korupsi ini direalisasikan dalam pembelajaran yang bermakna yaitu membangun pengalamanpengalaman baru bagi siswa melalui pemecahan masalah yang dialami oleh siswa yang didasarkan atas konsep-konsep yang relevan. Pembelajaran bermakna dapat terlaksana melalui perencanaan yang matang yaitu pembuatan rencana pelaksanaan pembelajaran (RPP), variasi metode pembelajaran, penggunaan media pembelajaran interaktif, hikmah/ makna pembelajaran yang aktual dan keteladanan dari lingkungan pendidikan anak.

\section{DAFTAR PUSTAKA}

Al-Attas., M. N. (1990). Konsep Pendidikan Islam, Suatu Kerangka Fikir Pembinaan Filsafat Pendidikan Islam. Bandung: Mizan.

Al-Nahlawi., A. (1992). Prinsip-Prinsip dan Metode Pendidikan Islam. Bandung: Diponegoro.

Andrian, R. (2017). Pembelajaran Bermakna Berbasis Post It. Jurnal Mudarrisuna, 7(1), 103-118.

Gaffar, A. (2016). Pendidikan Islam berbasis Anti Korupsi. El-Furqonia, 03(02), 195-206.

Harto, K. (2014). Pendidikan Anti Korupsi Berbasis Agama. Intizar, 20(01), 121138. https://doi.org/10.19109/intizar.v20i1.426

Hude, M. D. (2018). Mengemas Pembelajaran Pendidikan Islam yang Bermakna. Qiro'ah, 1(1), 25-43.

Imelda, A. (2017). Pendidikan Anti Korupsi Dalam Pendidikan Agama Islam. AlTadzkiyyah: Jurnal Pendidikan Islam, 8(1), 83. https://doi.org/10.24042/atjpi.v8i1.2098

Iswandi, I. (2019). Efektifitas Pendekatan Keteladanan Dalam Pembinaan Akhlak Siswa Di Min Bandar Gadang. Al-Tadzkiyyah: Jurnal Pendidikan Islam, 10(1), 113-136. https://doi.org/10.24042/atjpi.v10i1.3742

Mappasiara. (2018). PENDIDIKAN ISLAM (Pengertian, Ruang Lingkup dan Epistemologinya). Inspiratif Pendidikan, 7(1), 147 - . https://doi.org/10.24252/ip.v7i1.4940 
Mukhtar. (2013). Metode Praktis Penelitian Deskriptif Kualitatif. Jakarta: GP Press Group.

Shihab, M. Q. (2005). Tafsir Al-Mishbah: Pesan, Kesan dan Keserasian Al-Qur 'an. Cet III. Tangerang: Lentera Hati. 